\title{
Light gradients and meadow structure in Posidonia oceanica: ecomorphological and functional correlates
}

\author{
Josef Dalla Via*, Christian Sturmbauer, Gudrun Schönweger, Elisabeth Sötz, \\ Sylvie Mathekowitsch, Martin Stifter, Reinhard Rieger
}

Department of Zoology and Limnology, University of Innsbruck, Technikerstrasse 25, A-6020 Innsbruck, Austria

\begin{abstract}
Three interconnected light gradients and their influence on structure and function of seagrass leaves were investigated in both a shallow $(-3 \mathrm{~m}$ depth) and a deep $(-10 \mathrm{~m})$ stand of Posidonia oceanica (L.) Delile in Calví (Corse, France). Light attenuation in the water column amounted to 51.3 , 63.5 , and $79.3 \%$ irradiance of the subsurface value at $-2.5 \mathrm{~m}$ and $70.4,67.3$, and $98.1 \%$ at $-9.5 \mathrm{~m}$ depth for blue, green and red wavelengths, respectively. Horizontally lying fronds of bent $P$. oceanica leaves (between 30 and $50 \mathrm{~cm}$ above the bottom) induced a selfshading effect on the whole stand at both sampling sites, further reducing the already dimmed incident light of the blue, green and red wavelengths by $57-58,61-63$, and $51-53 \%$, respectively. Nevertheless, within the $P$. oceanica stand (at 0 and $30 \mathrm{~cm}$ above the bottom) similar light conditions were found at both sampling sites for blue and green wavelengths. Changes in the meadow structure of the deep stand make this possible: shoot density is reduced by $72 \%$, leaves are generally 5 to $10 \mathrm{~cm}$ shorter, maximal leaf length is reduced by $23.8 \%$, and dead tips are shorter compared to the shallow seagrass stand. The number of leaves per shoot and leaf blade width increase photosynthetically active surfaces at the deep stand. Pigment concentrations decreased in the order: chlorophyll $a$, chlorophyll $b$, and carotenoids. Along the length of a $P$. oceanica leaf $(0-10,30-40$, and the top live $10 \mathrm{~cm})$ highest pigment concentrations were found in the tips of juvenile leaves and the midsection of long leaves, restricting the highest photosynthetic rates to a layer between 20 and $40 \mathrm{~cm}$ above the bottom. The bases of short and juvenile leaves contain significantly higher concentrations of pigment at the deep site than at the shallow site, with generally higher concentrations in the basal sections of short than of long leaves. Epiphytes were responsible for the third light gradient, directly shading the photosynthetically active surface of $P$. oceanica, especially of long leaves, where they shaded up to almost $50 \%$ of the surface. The main epiphyte, the red crustose coralline alga Fosliella farinosa, shows a functional adaptation in its distribution: in the shaded deep stand it grows at the light-exposed convex surface of the P. oceanica leaf, whereas in the more highly irradiated shallow stand it can be found mainly in the shaded concave surface of the leaf, indicating a functional photoadaptation.
\end{abstract}

KEY WORDS: Sea grass · Light attenuation - Selfshading · Leaf morphometry · Epiphytes - Chlorophyll $\cdot$ Pigment concentration

\section{INTRODUCTION}

The seagrass Posidonia oceanica, a Mediterranean endemic species, plays an important role in the primary production of oligotrophic marine ecosystems. Seagrass distribution is closely linked to underwater

·E-mail: josef.dalla-via@uibk.ac.at light penetration and thus restricted to infralittoral depths, at which the irradiance of photosynthetically active radiation (PAR) is above approximately $4.5 \%$ of the subsurface value (Ott 1980, 1996)

Although seagrass is found down to a depth of $-90 \mathrm{~m}$, the distribution of Posidonia oceanica is usually limited to depths above $-35 \mathrm{~m}$ (Den Hartog 1970, Drew 1978, Duarte 1991). Several investigations have dealt with the primary production of seagrass meadows (Ott 1980, 
Wittmann \& Ott 1982, Bay 1984, Wittmann 1984, Pirc 1986, Pergent \& Pergent-Martini 1991, Buia et al. 1992, Pergent et al. 1994, Pergent-Martini et al. 1994); some have characterized the morphological parameters of the leaves at the upper and lower (depth) distribution limits in relation to the environment (Albergoni et al. 1978, Mariani et al. 1980, Mariani-Colombo et al. 1983 , Semroud et al. 1992). The relationship between seagrass morphology, pigment content and photosynthetic performance in relation to light availability has been studied in the eelgrass Zostera marina (Dennison \& Alberte 1982, 1985, 1986)

Published studies have usually ignored the fact that seagrass meadows are exposed not only to 1 but to 3 interconnected light gradients: firstly, the gradient via the water column down to the Posidonia meadow; secondly, the gradient due to selfshading of the Posidonia leaves within the Posidonia stand; and, thirdly, direct shading of the Posidonia leaves caused by epiphytes (see also Riedl 1966). Consequently, research should not be focused exclusively on extreme $P$. oceanica distributions in which the first light gradient is the major limiting factor, but also on lower water depths (in our case -3 and $-10 \mathrm{~m}$ ) so as to be able to measure selfshading effects. Moreover, the investigation of individual leaf sections from different depths within the $P$. oceanica stand can reveal more detailed insights into the effects of incident light gradients.

We have chosen such an approach in a fast growing Posidonia oceanica stand in the Mediterranean Sea, near Calví (Corse, France), where the primary leaf production per shoot is one of the highest compared to several other sites in the Mediterranean Sea (Calvi: $1530 \mathrm{mg}$ dry weight shoot ${ }^{-1} \mathrm{yr}^{-1}$; Mediterranean range: 310 to $1540 \mathrm{mg}$ dry weight shoot ${ }^{-1} \mathrm{Yr}^{-1}$; Pergent-Martini et al. 1994). The aim of our investigation was to identify ecomorphological and functional parameters of the leaf blades in connection with light gradients effective at 2 experimental sites, at -3 and $-10 \mathrm{~m}$ depth.

\section{MATERIAL AND METHODS}

The investigation was carried out in September 1996 at the Station de Recherches Sous-Marines et Océanographiques (STARESO) near Calví (Corse, France). Two undisturbed seagrass meadows with homogeneous stands of Posidonia oceanica with occasional presence of boulders were chosen as investigation sites, a 'shallow site' in the Anse de l'Oscelluccia at $-3 \mathrm{~m}$ depth (at $42^{\circ} 34^{\prime} 34^{\prime \prime} \mathrm{N}, 8^{\circ} 43^{\prime} 27^{\prime \prime} \mathrm{E}$ ) and a 'deep site' at $-10 \mathrm{~m}$ near the station (at $42^{\circ} 34^{\prime} 48^{\prime \prime} \mathrm{N}$, $8^{\circ} 43^{\prime} 29^{\prime \prime} \mathrm{E}$ ), the 2 sites being only about $430 \mathrm{~m}$ apart (repeated satellite bearings with Magellan 3000, Magellan Systems Corp., San Dimas, CA, USA). For both sampling sites light gradients in the water column and shading by $P$. oceanica leaves were measured. Shoot density and length distribution of the leaves were assessed, and shoots were collected from both sites for chlorophyll determination. On the long leaves the distribution of major groups of epiphytes was determined.

Morphometric parameters. In $25 \times 25 \mathrm{~cm}$ grid squares $(\mathrm{n}=5)$ shoot density was determined at both sites; leaves were collected from the entire square and leaf length distribution measured with rulers and calipers. The leaves were classified as short (length $<10 \mathrm{~cm}$ ), intermediate $(10 \mathrm{~cm}<$ length $<30 \mathrm{~cm})$ and long (length $>30 \mathrm{~cm}$ ) specimens. Each leaf was divided into up to 3 sections, depending on its length: section $A$ - the lowest $10 \mathrm{~cm}$ of a leaf; section $\mathrm{B}$-the intermediate section between 30 and $40 \mathrm{~cm}$; section $\mathrm{C}$ - the uppermost live $10 \mathrm{~cm}$ of a leaf, for which we distinguished between the last live $10 \mathrm{~cm}$ in intermediate leaves (C1) and long leaves ( $\mathrm{C} 2$ ). A leaf section was regarded as alive when chlorophyll pigmentation was still visible. Total and live leaf length (i.e. total length minus dead leaf tips) were measured, as well as width, thickness and weight of each section.

Representatives of each leaf section of long leaves from both sampling sites were fixed in $70 \%$ alcohol, resin-embedded (Technovit 7100, Heraeus Kulzer GmbH, Wehrheim, Germany), stained according to Richardson et al. (1960) and then used for the determination of epidermal thickness and number of hypodermal fiber cells along 5 equidistant segments at the concave and convex leaf surface. The values obtained were combined for analyses since no statistical differences among the segments were found. Slices from 6 to 8 different leaves (for each leaf section and at both sampling sites) were investigated

Light measurements. At both sites diurnal rhythms of light profiles in the water were measured. Depth profiles of light conditions in the water column were measured every hour from dawn until dusk at depth increments of $1 \mathrm{~m}$. Shading caused by the Posidonia oceanica leaves within the $P$. oceanica stand was measured simultaneously 0,30 , and $50 \mathrm{~cm}$ above the bottom). Every hourly profile was measured twice (downwards and upwards combining the data to a single value). The underwater light measurements were discrete and carried out with a flat sensor, an opto-electronic integrated circuit containing a photodiode and an on-chip transimpedance amplifier (OPT209, BurrBrown Corp., Tucson, AZ, USA) with inserted absorption color filter and a white diffuser. Blue, green and red filters with the following spectral ranges were used as color filters (Dirmhirn 1964): blue filter (Schott BG12) - range 395 to $515 \mathrm{~nm}$, optimum wavelength

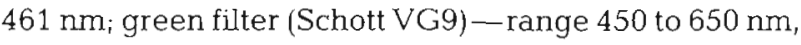


optimum wavelength $535 \mathrm{~nm}$; red filter (Schott RG2)range 590 to $835 \mathrm{~nm}$, optimum wavelength $660 \mathrm{~nm}$. The diurnal pattern of total solar radiation on the surface was determined with a solar energy sensor, a blue-enhanced precision silicone photodiode (Type ESR, DeltaT Devices, Cambridge, UK). For all light measurements carried out, the sky was clear and cloudless. All times are given in Mid-European sun time (GMT + 1.00) rather than Mid-European summer time (GMT + 2.00). Due to the equinox in September we encountered an intermediate light season between high irradiance in summer and reduced irradiance in winter. These light values can also be extrapolated to springtime.

Pigment measurements. The shoots collected for pigment measurements were immediately transferred to black plastic bags (already underwater) to avoid pigment deactivation by sunlight and transported to the laboratory for measurement. The measured leaf sections were cut with scissors and macerated in a porcelain mortar by adding approximately 5 to $10 \mathrm{ml}$ acetone and a small amount of fired quartz sand. The homogenate was stored in a refrigerator overnight (at least $12 \mathrm{~h}$ ), then filtered through a glass fiber filter (Whatman $\mathrm{GF} / \mathrm{F}$ ) which was washed with acetone; the final volume of the extract was noted and its absorption measured at 480, 510,630,647,664 and $750 \mathrm{~nm}$. All obtained extinctions were corrected for acetone (blank) and turbidity (750 nm). Care was taken to work in darkened facilities (e.g. hood, refrigerator, dark plastic bags, etc.) or in containers and glassware covered with aluminum foil to avoid pigment deactivation by daylight. The concentrations of chlorophyll a (chl a), chlorophyll $b(\mathrm{chl} b)$ and carotenoids were determined with the following equations (Lorenzen 1967. Strickland \& Parsons 1968):

$$
\begin{aligned}
& C(\mathrm{chl} a)=11.85 \mathrm{E}_{664}-1.54 \mathrm{E}_{647}-0.08 \mathrm{E}_{630} \\
& C(\mathrm{chl} b)=20.97 \mathrm{E}_{647}-3.94 \mathrm{E}_{664}-3.66 \mathrm{E}_{630} \\
& C(\text { plant carotenoids })=7.6\left(\mathrm{E}_{480}-1.49 \mathrm{E}_{510}\right)
\end{aligned}
$$

where $E$ is the absorbance at different wavelengths (corrected for the $750 \mathrm{~nm}$ reading). The measured values were corrected for the various dilutions during sample preparation and related to biomass.

Epiphytes. Epiphytic fauna and flora were investigated on long leaves $(>30 \mathrm{~cm}$ ) from both sampling sites with special emphasis given to sections $A, B$, and $T$ (tip of the leaf regardless whether this section was dead or not). $2 \mathrm{~cm}$ long parts were cut from the sections, both surfaces checked under a binocular microscope and drawn using a drawing mirror. The outline of the leaf section and the outlines of all epiphyte groups were drawn on squared paper and the respective areas determined by counting the squares. A variation coefficient of $5 \%$ was obtained by counting the same preparation several times for error estimation. Since the leaves showed a slight (at the shallow site) to strong (at the deep site) curvature around their length axis, the concave surface of the leaf was defined as the 'inner surface' and the convex surface as the 'outer surface'. Both surfaces were individually drawn and evaluated in a total of 82 drawings. The following species and species groups were chosen as epiphyte categories: Fosliella farinosa (Lam.) Howe (Rhodophyceae, Corallinaceae), a red crustose coralline alga; other algae without species distinction; Electra posidoniae (Gautier) (Bryozoa); other Bryozoa without species distinction; Foraminifera. With the exception of the sedentary polychaete Spirorbis pagenstecheri (Quatref.), these comprised all representatives of leaf epiphytes. Single specimens of $S$. pagenstecheri were found sporadically at deep sites only and were not considered in the graphs. Due to the high biological variations, only the most commonly found epiphyte group (F. farinosa) was statistically evaluated. Nevertheless, all other groups were included in the graphs in order to obtain a better estimate of total epiphyte area. To improve our knowledge of the epiphyte gradient an additional intermediate depth of $-5 \mathrm{~m}$ was sampled. The sampling site was situated between the shallow and deep sites.

Temperature measurements. At both sampling sites temperature-data-loggers were mounted in the Posidonia oceanica stands close to the bottom (at -3 and $-10 \mathrm{~m}$ depth) and at $50 \mathrm{~cm}$ above the bottom in the $P$. oceanica bed $(-2.5 \mathrm{~m}$ and $-9.5 \mathrm{~m}$ ) (Optic Stow Away Temp WTA32, Onset, Pocasset, MA, USA). Continuous measurements over $1 \mathrm{wk}$ at sampling intervals of $1 \mathrm{~min}$ were taken.

Statistics. Statistical analysis was performed using STATISTICA (StatSoft Inc. 1995, release 5.0). All statistical comparisons were performed using the non parametric Mann-Whitney $U$-test, indicating differences at the $p<0.05$ and $p<0.01$ levels. Values in the text and graphs are given as means \pm standard deviations.

\section{RESULTS}

\section{Posidonia oceanica bed structure and morphometry}

The 2 sites of Posidonia oceanica showed significant differences in their structures. Shoot density significantly decreased with increasing depth $(-3$ to $-10 \mathrm{~m}$ ) from $973 \pm 281$ to $267 \pm 79$ shoots $\mathrm{m}^{-2}$; however, the mean number of leaves per shoot rose significantly from 5.6 to 6.9 leaves shoot ${ }^{-1}$ (Fig. 1). The distribution of leaf lengths showed differences as well: at the shallow site the most common lengths were between 10 and $15 \mathrm{~cm}$ with a further peak at approximately $55 \mathrm{~cm}$, whereas at the deep site frequent lengths were 


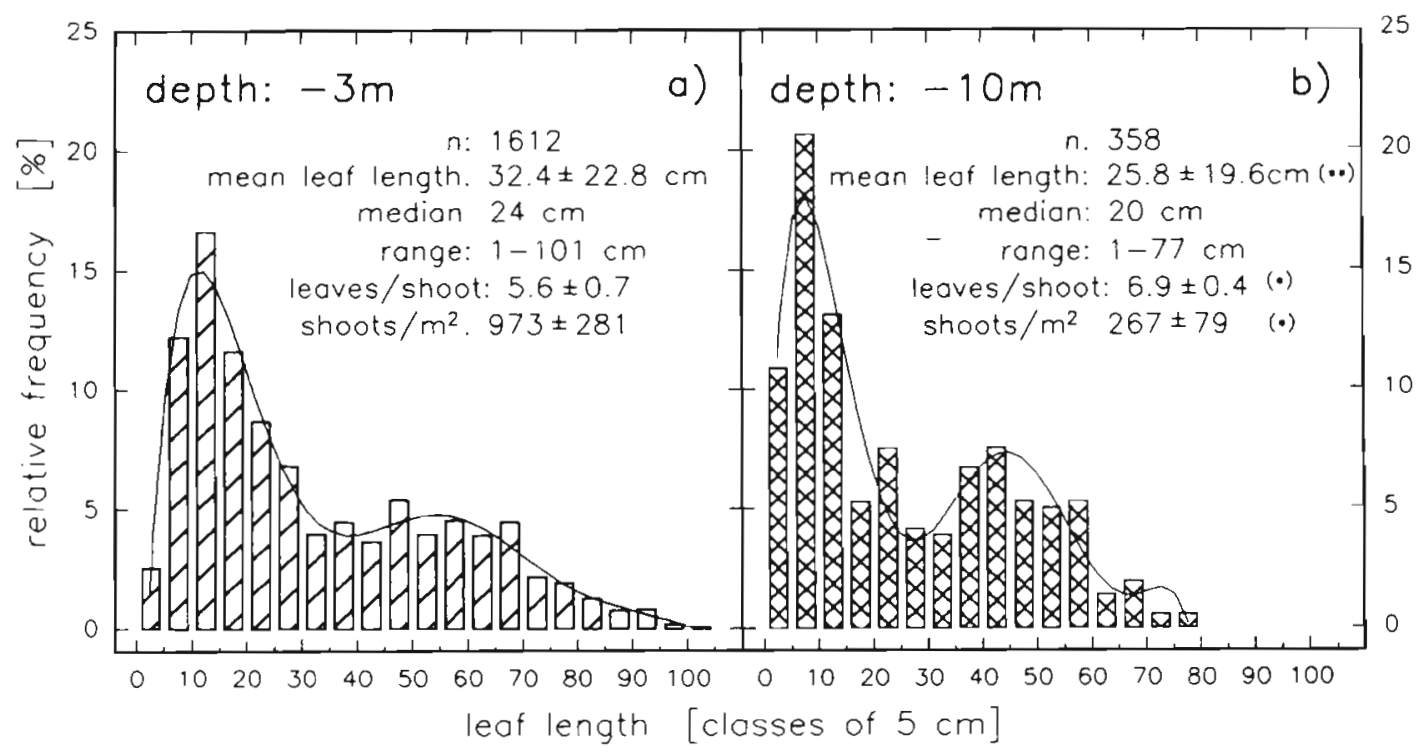

Fig. 1. Posidonia oceanica. Relative frequency of leaf length distribution (arranged in classes of $5 \mathrm{~cm}$ ) for leaves at (a) $-3 \mathrm{~m}$ and (b) $-10 \mathrm{~m}$ depth. Distribution parameters are given for each site. The polynomial fits are, for the shallow site, $y=-8.82+5.45 x-0.43 x^{2}+$ $0.014 x^{3}-2.29 \times 10^{-4} x^{4}+1.58 \times 10^{-6} x^{5}+6.52 \times 10^{-10} x^{6}-6.46 \times 10^{-11} x^{7}+2.38 \times 10^{-13} x^{8}(\mathrm{r}=0.99)$ and, for the deep site, $y=0.597+5.96 x$ $-0.67 x^{2}+0.03 x^{3}-6.17 \times 10^{-4} x^{4}+6.13 \times 10^{-6} x^{5}-2.34 \times 10^{-8} x^{6}(r=0.95)$. Significant differences between sites: $" p<0.05, \cdots p<0.01$
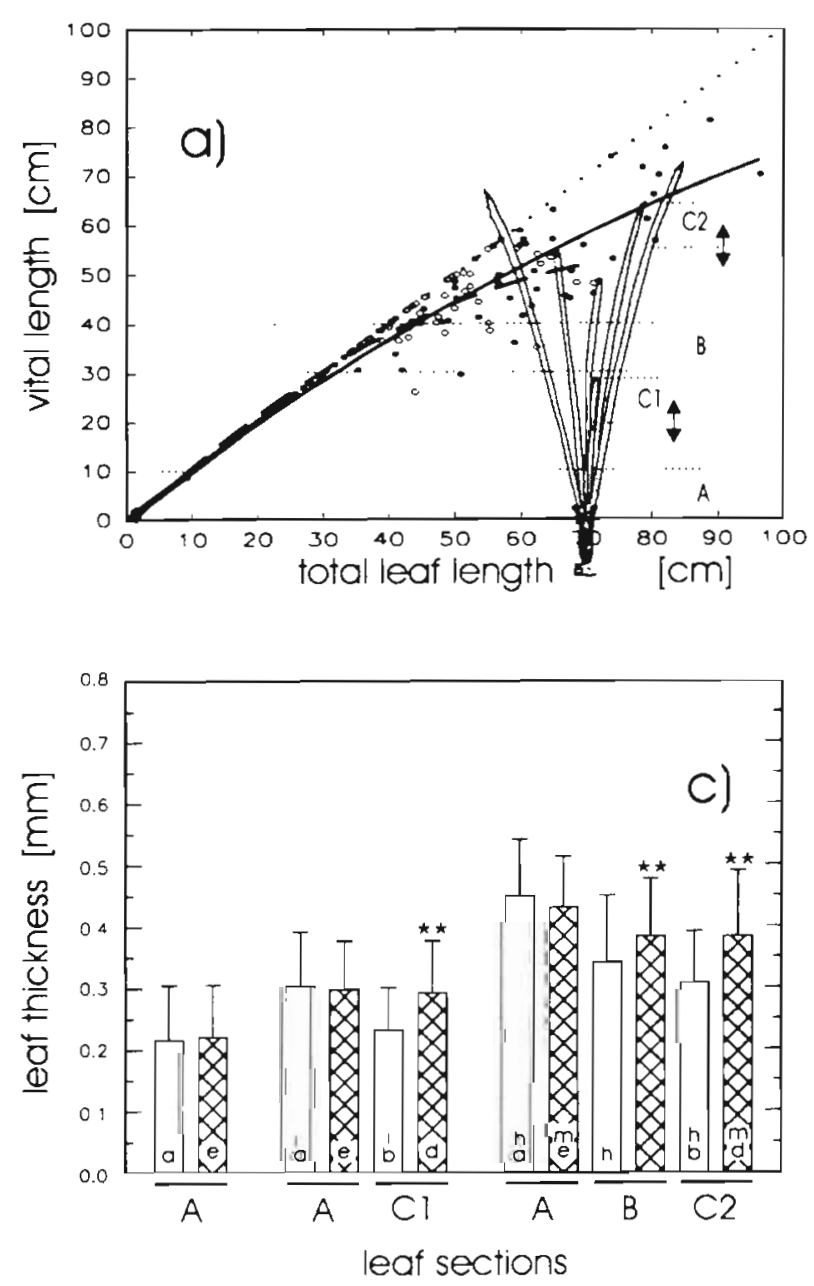

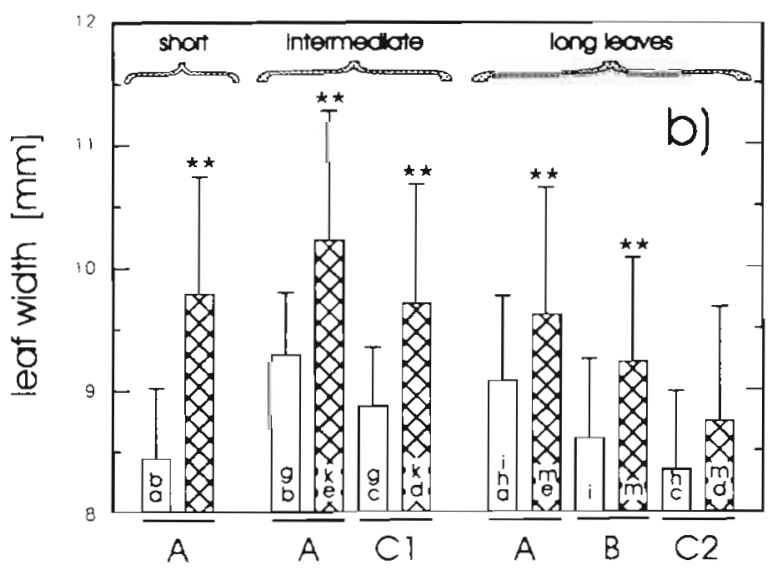

Fig. 2. Posidonia oceanica. Morphometric parameters in leaves at the shallow site (empty bars) and the deep site (crosshatched bars). (a) total leaf blade length vs live blade length. $(\bullet)$ Values from the shallow site with solid line as regression $(y=0.41+$ $\left.1.01 x-2.7 \times 10^{-3} x^{2} ; r=0.98\right)$. (0) Values from the deep site with the dashed line as regression $\left(y=-1.37+1.27 x-0.01 x^{2} ; r=0.99\right)$. Dotted line represents the isoline at which total leaf length equals live length. (b) Leaf blade width and (c) thickness of different sections and leaves are given as means + standard deviation. The leaves were divided into short $1<10 \mathrm{~cm}$ total vital length: only leaf section $\mathrm{A})$, intermediate $(10 \mathrm{~cm}<x<30 \mathrm{~cm}$ total vital lengthi leaf sections $A$ and $C 1$ ), and long leaves $(>30 \mathrm{~cm}$ total vital length; leaf sections $A, B$, and $C 2$ ). Sections $C 1$ and $C 2$ refer to the top $10 \mathrm{~cm}$ of the vital leaf and not to the dead tips. Significant differences in leaf section parameters between sites " $p<0.05, \cdots p<0.01$. Similar leaf sections in leaves of different length were compared within site. A comparison of the sections of each leaf also revealed significant differences (shallow site, g, $h, i: p<0.05$ at least; deep site, $k, m, n: p<0.05$ at best). Columns with the same letter are significantly different 
5 to $10 \mathrm{~cm}$ with a second peak at $45 \mathrm{~cm}$. The leaves at the shallow site were longer (range 1 to $101 \mathrm{~cm}$, mean $32.4 \pm 22.8$; Fig. 1a) than those at the deep site (range 1 to $77 \mathrm{~cm}$, mean $25.8 \pm 19.6$; Fig. $1 \mathrm{~b}$ ). While leaves shorter than $30 \mathrm{~cm}$ had no dead tips, the dead portion increased with increasing leaf length up to $25 \%$ of total length (Fig. 2a).

The Posidonia aceanica leaves from the deep site were significantly wider (5 to $15 \%$ ) than those from the shallow site (Fig. 2b). In addition, leaves from both sites were wider at the base than at the top.

Only in the older leaf sections (C1, B, C2) was leaf thickness significantly larger at the deep site compared to the shallow site (Fig. 2c). At both sites the basal section (section $A$ ) became increasingly thicker with increasing age of the leaf, and each leaf became significantly thinner towards the tip (sections C1, B, C2). An estimated error of 10 to $15 \%$ from using the caliper to measure leaf thickness may affect the data.

\section{Light}

Light conditions above the water's surface measured over 1 day resulted in a Gaussian distribution with a maximum of total solar irradiance of $815 \mathrm{~W} \mathrm{~m}^{-2}$ at noon. The light data correspond closely to the pattern of diurnal variation in solar irradiance as calculated by Kirk (1994, p. 26-40). Assuming September 10 to be a standard day (date around which light measurements were carried out), a day length of $12.61 \mathrm{~h}$ can be calculated with a noon solar elevation of $\beta=52^{\circ}$ at our given latitude. Daily insolation, i.e. the total solar radiant energy received per unit horizontal area during the day $\left(Q_{s}\right)$, can thus be calculated, which, in our case, amounted to $23.5 \mathrm{MJ} \mathrm{m}^{-2}$. When the sun was in its zenith between 10:00 and 15:00 $\mathrm{h}, \mathrm{Q}_{\mathrm{s}}$ amounted to 13.8 $\mathrm{MJ} \mathrm{m}^{-2}$, which was $58.7 \%$ of total daily insolation. Transmission across the air-water interface reduces daily insolation due to the reflectance of the water surface. Calculating the reflectance as a function of zenith angle of light (Kirk 1994, p. 40-45), the daily insolation between 10:00 and 15:00 h is reduced by only $2.6 \%$, whereas daily insolation of the remaining periods (with low angle of the sun) is reduced by $11.6 \%$ due to light reflection at the water surface.

Light conditions underwater are shown in Fig. 3. At the shallow site (Fig. 3a) as well as at the deep site (Fig. 3b) light intensities strongly decreased within the water column. The intensities between 10:00 and 15:00 $\mathrm{h}$ were summarized and compared with the daily dusk and dawn values, which had high portions of stray light and lower absolute light intensity (06:00 to 09:00 $\mathrm{h} ; 16: 00$ to $19: 00 \mathrm{~h}$ ). Blue and green light wavelengths, expressed in per cent of subsurface intensity, were more attenuated during the time of most intensive insolation (10:00 to $15: 00 \mathrm{~h})$ than at dawn and dusk, but this was not the case for red light (Fig. 3a, b). The Posidonia oceanica meadow itself receives only a small portion of the subsurface light intensity: at the shallow site the $P$, oceanica is reached by $48.7,36.5$ and $20.7 \%$ of the blue, green and red subsurface light portions, respectively, while only $29.6,32.7$ and $1.9 \%$ reach the deep $P$. oceanica meadows (Fig. $3 c, 50 \mathrm{~cm}$ above sea bottom). Within the $P$. oceanica bed itself, light is further reduced by selfshading. We found similar intensities of blue and green wavelengths, whereas significant differences between the shallow and the deep site were found with respect to the red spectrum. Due to selfshading in the P. oceanica stand, all wavelength ranges showed a significant decrease of intensity towards the bottom, with only 10 to $20 \%$ of the subsurface light intensity at $30 \mathrm{~cm}$ above sea bottom serving as an energy source for photosynthesis (Fig. 3c). For all light spectra and in both sampling areas light intensity at the bottom was reduced to less than $3 \%$ of the subsurface value (Fig. $3 c$ ).

\section{Pigments}

Concentrations of the most important pigments (chl $a_{\text {, }}$ chl $b$, and carotenoids) of individual leaf sections are summarized in Fig. 4, with chl a having the highest concentrations in the leaf (Fig. $4 \mathrm{~b}$ ), followed by chl $b$ (Fig. 4c) and the carotenoids (Fig. 4d). The highest pigment concentrations were found in the tips of intermediate leaves (section $\mathrm{C} 1$ ). When we compared shallow and deep sites, higher pigment concentrations were found in leaf section $\mathrm{A}$ of short and intermediate leaves from the deep site, whereas pigment concentrations in the tips (section C2) of old (i.e. long) leaves were significantly lower at the deep site. Comparing the same sections within the same sampling area, we found a similar pattern for all 3 pigments: section $A$ of long leaves contains significantly less pigment than section $\mathrm{A}$ of intermediate and short leaves, the pigment concentrations of these last two not differing significantly from one another. A comparison of sections $\mathrm{C} 1$ and $\mathrm{C} 2$ shows that the end section of long leaves (C2) always had significantly lower pigment concentrations than that of intermediate leaves (section $\mathrm{C} 1$ ). When the different sections within a single leaf $(A, C 1$ for intermediate leaves and $A, B, C 2$ for long leaves) are compared, it becomes clear that (1) the tip of intermediate leaves (section C1) always contain the highest pigment concentrations and (2) the midsection of long leaves (section B) always have a significantly higher pigment concentration than the base (section A) and tip ( $\mathrm{C} 2$; except carotenoids in the shallow site). 


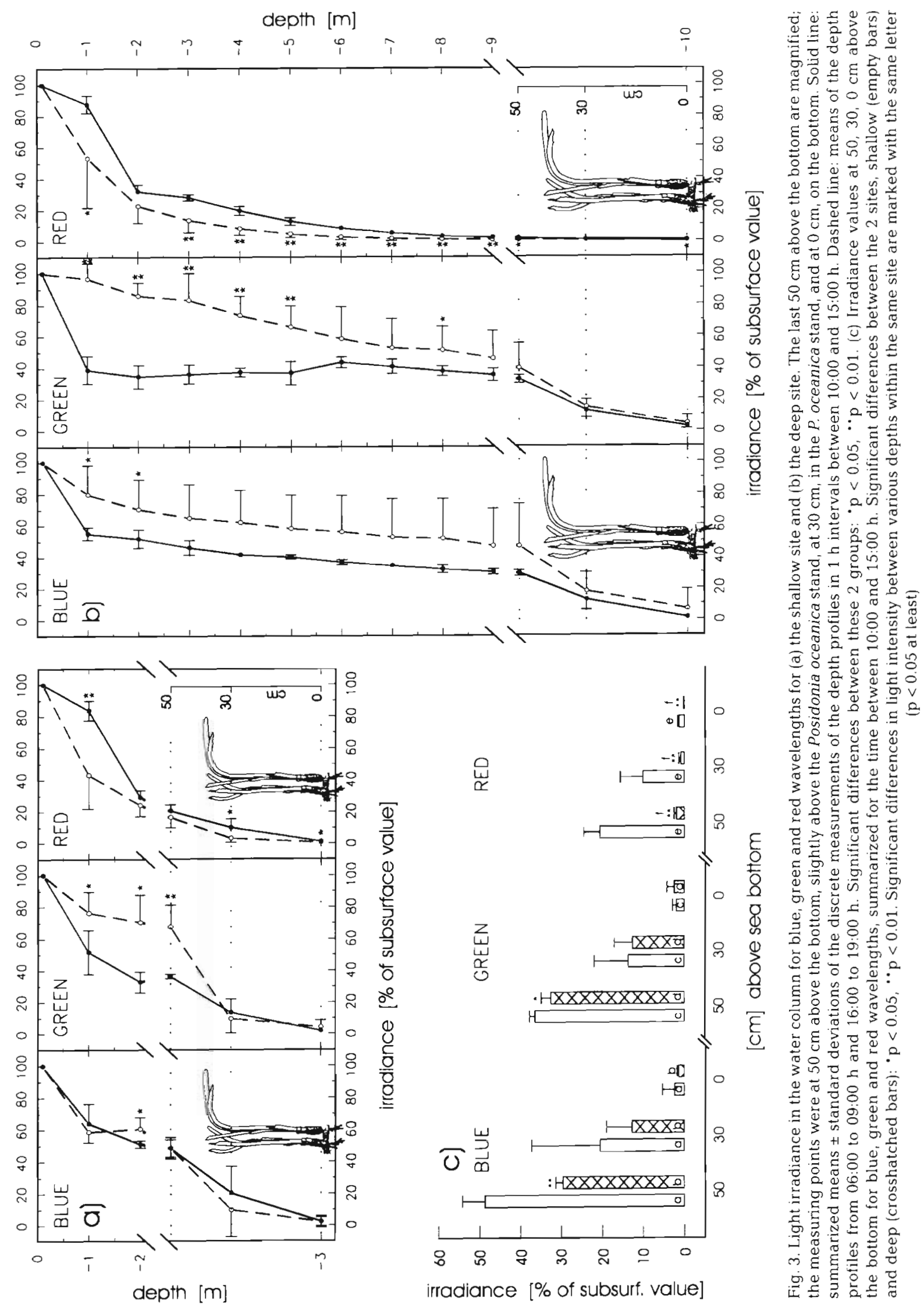



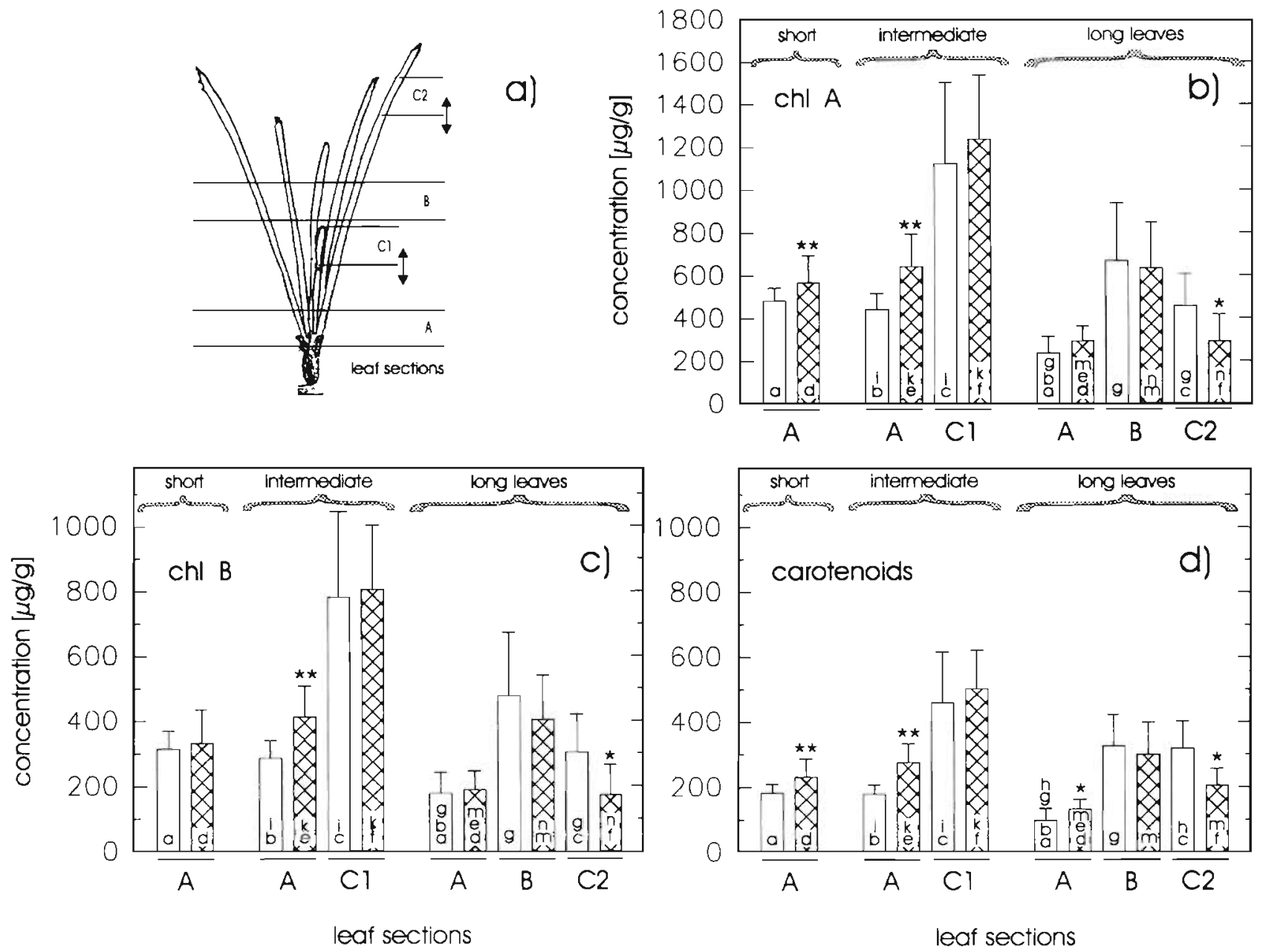

Fig. 1. Posidonia oceanica. Comparison of pigment concentrations in leaf sections from the shallow site (empty bars) and the deep site (crosshatched bars). (a) Leaf section classification (see legend to Fig. 2). Pigment concentrations for the different sections are given in $\mu \mathrm{g} \mathrm{g}^{-1}$ leaf fresh weight for (b) chl $a$, (c) chl b, and (d) carotenoids. Significant differences of pigment concentrations of the different leaf sections between sites: ${ }^{*} p<0.05, \cdots p<0.01$. Similar leaf sections in leaves of different length were compared within the shallow site $(a, b, c: p<0.01$, except $c$ in carotenoids is $p<0.05)$ and the deep site ( $d, e, f: p<0.01)$. A comparison of sections within each leaf also revealed significant differences (shallow site, $g, h, i: p<0.05$; deep site, $k, m, n$ : $p<0.05$ ). Columns with the same letter are significantly different

\section{Epiphytes and leaf stability}

The area covered and therefore the intensity of the shade provided by epiphytes increased significantly towards the tip with the areas of lowest shading by epiphytes being at the basal section of the leaves (section A) and higher shading levels in the midsections (section $B$ ) and the tip (section T) (Fig. 5). The major component of these epiphytes, Fosliella farinosa, shows, however, different distributions between the inner and outer leaf surfaces: at the shallow site the inner surface was most frequently colonized, whereas in the deep Posidonia oceanicastand the outer surfaces are more often affected (Fig. 5). This is particularly true for the tips (section T), but also for the midsections (section B) of long P. oceanica leaves.
Measurements of the epidermal thickness of Posidonia oceanica leaf blades revealed a significantly thicker epidermis for the outer surface than for the inner surface. This is true for all leaf sections in both sampling areas (Fig. 6a). Epidermal thickness in section $A$ is significantly lower compared to sections $B$ and $C$, which are located higher on the leaf, with the last 2 not being significantly different from one another (except the inner surface at the deep site). Differences between the 2 sites were found only for section $B$ and the inner surface of section $\mathrm{C}$ (Fig. 6a).

The number of hypodermal fiber cells did not differ between inner and outer surfaces of the leaves in all sections and both sampling areas (Fig. 6b). Differences between the 2 sites were limited to the basal leaf sec- 

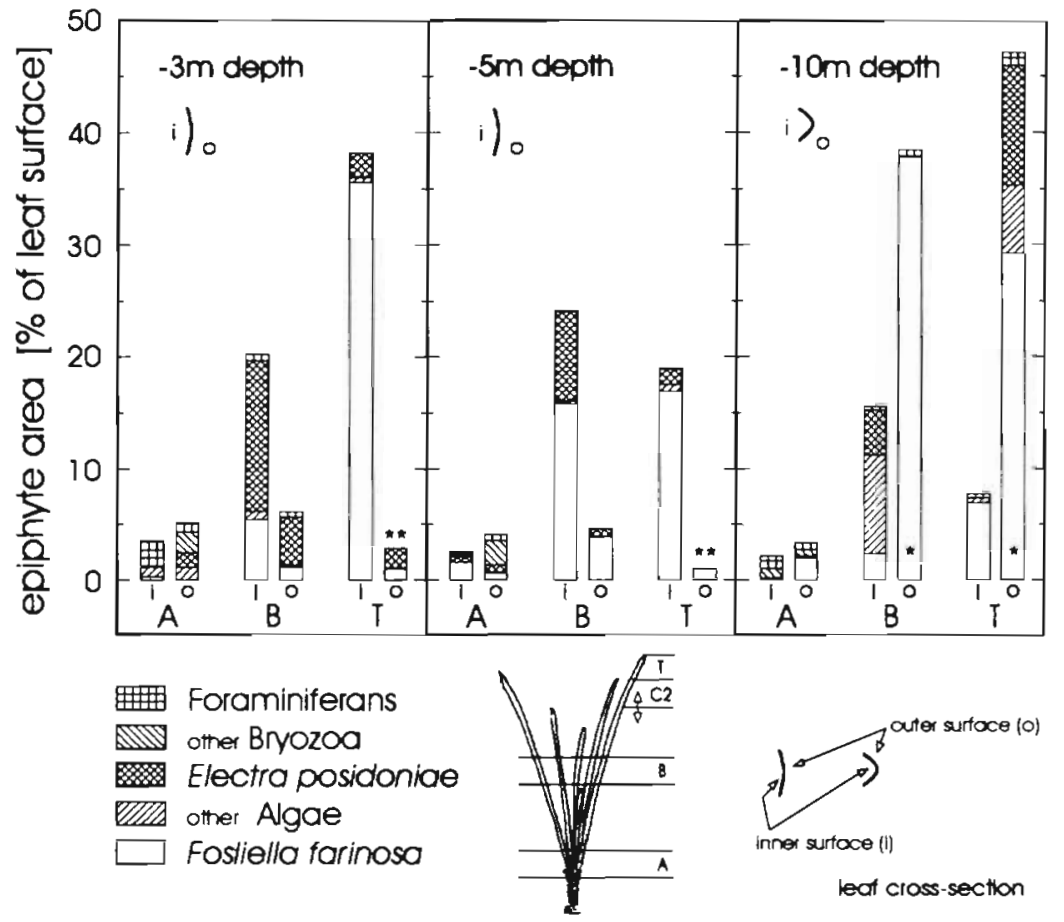

Fig. 5. Epiphyte area at depths of $-3,-5$ and $-10 \mathrm{~m}$, depicted as stacked bars for the different epiphyte groups. For the major component of the epiphytes, the red crustose coralline alga Fosliella farinosa, significant differences were found between inner surface (i) and outer surface of the leaf blade (o): $p<$ $0.05, \cdots p<0.01$

tion (section A), where Posidonia oceanica leaves from the deep stand showed fewer fiber cells per unit of length (except the inner surface in section C). Comparing the different leaf sections of a single leaf, it becomes clear that a significantly higher number of fiber cells props up the leaf at its basal section (section A), whereas the upper sections ( $B$ and $C$ ) show a lower number of fiber cells without any difference between these sections (except for the outer surface at the deep sampling area) (Fig. 6b).

\section{DISCUSSION}

Light and temperature associated with the solar cycle are the main factors influencing growth and distribution of seagrass meadows. Comparisons among several geographically isolated Posidonia oceanica meadows revealed a 43 to $46 \%$ variability in shoot size and growth due to light and temperature influences and only a 9 to $12 \%$ variability between the various sites due to local factors such as nutrients or dissolved inorganic carbon (Alcoverro et al. 1995). An endogenous component not depending on temperature and illumination also determines seasonal growth rhythm in P. oceanica (Ott 1979). The relative importance of these factors in influencing growth seasonality may depend on how restricted the light source is or on depth of occurrence of a specific $P$. oceanica stand.

Posidonia oceanica stands are exposed to 3 interconnected light gradients: (1) in the water column due to light attenuation with increasing depth, (2) within the $P$. oceanica stand due to selfshading, and (3) directly at the $P$. oceanica leaf due to shading by epiphytes.

\section{Light gradient and temperature in the water column}

In shading experiments Posidonia australis, after a $90 \%$ reduction of the incident light, a more than 50\% lower leaf growth rate and a significant reduction in live shoot density and shoot weight was found in the shaded areas compared to unshaded control sites. Loss of leaves and shoot death were the main reasons for these changes, even within 1 mo (Fitzpatrick \& Kirkman 1995). A decrease in shoot density with increasing depth is a common reaction in Posidonia to altered light conditions (Buia et al. 1992, Fitzpatrick \& Kirkman 1995). In our study shoot density at the deep site measured only $27 \%$ of that at the shallow site (Fig. 1). Due to the thinned out shoot density at the deep site, almost identical light conditions were reached in both $P$. oceanica stands (at -3 and $-10 \mathrm{~m}$ ): the blue and green wavelengths 30 and $0 \mathrm{~cm}$ above the button showed no significant differences between the deep and shallow site, although almost $40 \%$ less blue light and 10\% less green light reached the deep site (Fig. 3c). In addition, the deep site lacked almost the entire red spectrum (less than $2 \%$ of subsurface irradiance reaching the $P$. oceanica stand; Fig. 3c). Increasing the photosynthetically active surface with significantly wider leaves and higher number of leaves per shoot (Figs. 1 \& 2b), however, seems to only partly compensate for the poorer light conditions at the deep site. Deep site leaves were considerably shorter than those at the shallow site, not only with respect to maximum length (Fig. 2a) but also with respect to the peaks of frequency distribution (Fig. 1). This may be due to different temperature conditions at the 2 sites within the annual cycle, with a more pronounced warming of the surface waters in early summer and a thermocline which only gradually reaches greater depths. Thermocline changes at $10 \mathrm{~m}$ depth were also observed in August, with tempera- 


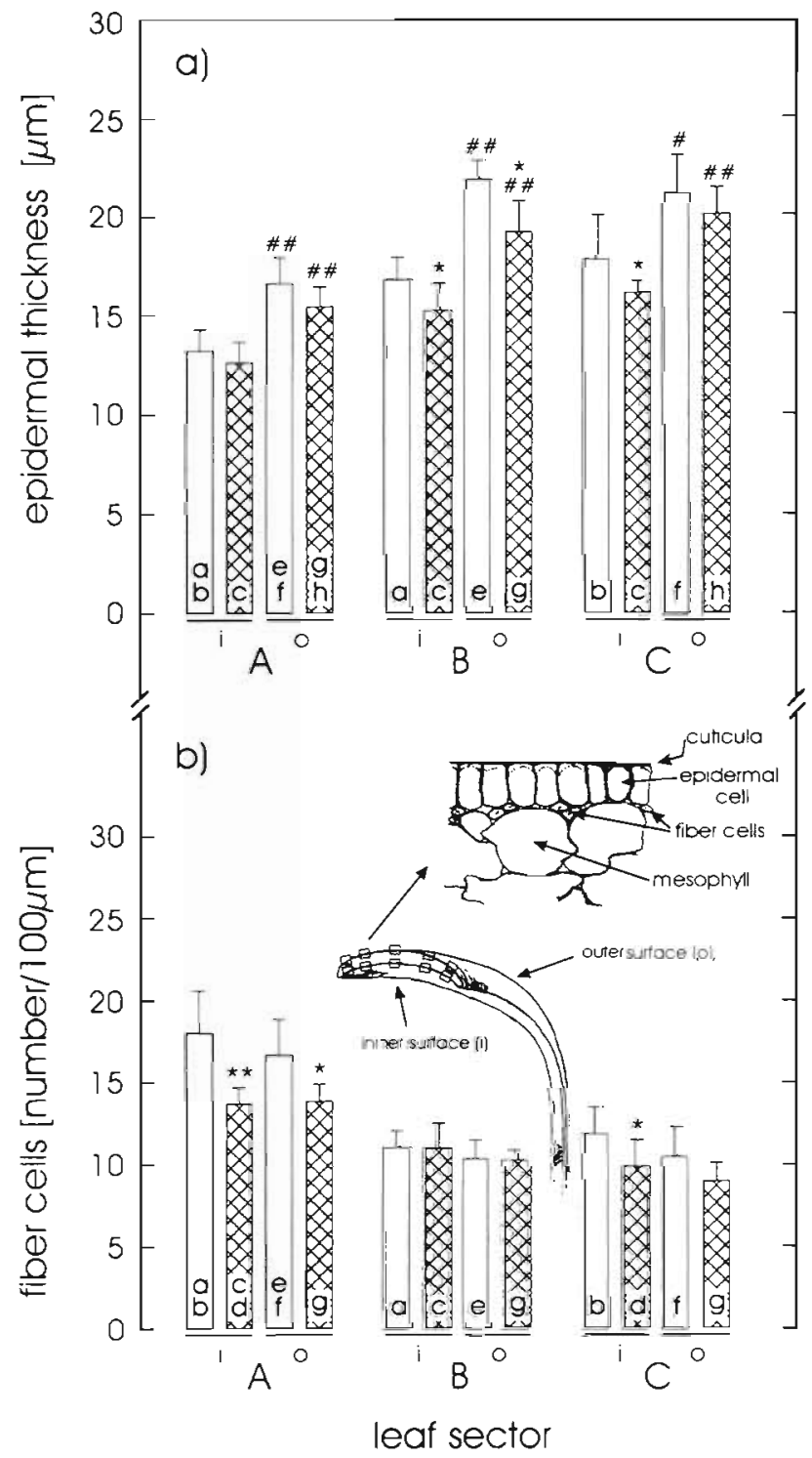

Fig. 6. Posidonia oceanica. Comparison of (a) epidermal thickness and (b) number of hypodermal fiber cells in different leaf sections of long leaves. Significant differences between inner (i) and outer (o) surface of the leaf (within the same leaf section) are marked by \# $(p<0.05)$ and \#\# $(p<0.01)$ for the shallow site (empty bars) and the deep site (crosshatched bars). Significant differences between sites are marked by " $p<0.05$ and $" p<0.01$. A comparison of the inner surfaces (shallow site, $a, b: p<0.01$; deep site, $c, d$ : $p<0.01$ ) and the outer surfaces (shallow site, e, f: $p<0.01$; deep site, $g, h: p<0.01$, except $c$ in epidermal thickness and $g$ in fiber cells are $p<0.05$ ) along individual sections revealed significant differences. Columns with the same letters are significantly different. A leaf cross section with the marked measured segments and a schematic depiction thereof are inserted in (b)

tures fluctuating rapidly between 24 and $17^{\circ} \mathrm{C}$ (Bay 1984). Buia \& Mazzella (1991) and Buia et al. (1992) also found that the appearance of flowers and new, juvenile and intermediate leaves of $P$. oceanica during the annual growth cycle was delayed by 1 to 3 mo at $-22 \mathrm{~m}$ depth compared to a shallow stand at $-5 \mathrm{~m}$. Shorter average leaf length may, therefore, be explained by a 'thermal delay' and a consequently lower growth rate. Due to high remixing of the water layers by storms during our investigation period, we found only small thermal differences at the sampling sites in September (shallow site: $22.25 \pm 0.33^{\circ} \mathrm{C}_{\text {i }}$ deep site: $22.31 \pm 0.24^{\circ} \mathrm{C}$ ), showing that thermal differences may occur in late spring or early summer but not in autumn.

\section{Selishading in Posidonia oceanica meadows}

A reduction in shoot density caused a reduction in selfshading by Posidonia oceanica leaves at the deep site, and light conditions within the stand became, therefore, similar at both sites (Fig. 3c, 30 and $0 \mathrm{~cm}$ above bottom). Since chlorophyll content and gross photosynthesis of leaf sections along $P$. oceanica leaves are positively correlated (Drew 1978), and the light absorbed per unit leaf biomass increases linearly with increasing pigment packaging (Enríquez et al. 1992), one can expect the highest photosynthetic rate in the tips of intermediate leaves (Fig. 4, section C1) and in section $B$ of long leaves (Fig. 4). These sections are mainly found 20 to $40 \mathrm{~cm}$ above the bottom and receive $20.5,13.6$ and $10.1 \%$ respectively of subsurface irradiance of blue, green and red light in the shallow site (Fig. 3), whereas the respective values for the deep site are $12.7,12.6$ and $0.89 \%$. These light intensities are further attenuated by more than $75 \%$ along the light path to the bottom, only $30 \mathrm{~cm}$ deeper.

Thus, an undifferentiated analysis of leaf blade pigments of whole leaves is unlikely to show any difference in pigment concentration with increasing water depth (Petit 1960, Margalef 1961, Augier \& Maudinas 1977), except that a higher degree of pollution causes poorer light conditions (Augier \& Maudinas 1977). We investigated individual leaf sections in young, juvenile and adult leaves (short, intermediate and long leaves, Fig. 4) and found significantly higher pigment concentrations at the deep site particularly at the basal section (section A, Fig. 4) as compared to the shallow site. Pigment distribution along the leaf is not uniform and particularly in adult leaves high pigment concentrations are found only in midsection $B$. Dead leaf tips can amount to up to $25 \%$ of total leaf length (Fig. 2a). They are not available for photosynthesis and lie flat on the stand, thus shading the meadow. Comparing the irradiance values just above the Posidonia oceanica stand (50 $\mathrm{cm}$ above sea bottom) with those just below the top layer of the stand ( $30 \mathrm{~cm}$ above sea bottom), it becomes 
clear that at the shallow site $58 \%$ of the blue light, $63 \%$ of the green light and $51 \%$ of the red light are shaded by the top horizontal layer of the $P$. oceanica stand. At the deep site $57 \%$ of the blue light, $61 \%$ of the green light and $53 \%$ of the red light are shaded by the top $P$. oceanica layer (Fig. 3c). Hence, the degree of relative shading in the top layers is quite similar at both sites. There is, however, an important difference: the $P$. oceanica leaves at the shallow site can 'afford' long dead tips (1) due to higher light intensities and (2) due to the high probability of wave orbitals severely tousling the top leaf tips of shallow site $P$. oceanica during storms thus rendering the upper portion of the seagrass stand more transparent to light. The loss of leaves or part of the fronds through the mechanical action of the water may therefore remove part of the selfshading effects of the dead leaf biomass and get rid of a large portion of shading epiphytes. If tips are not removed, their shading effect might inhibit photosynthesis more strongly in the lower layers of the stand. At the deep site shorter leaf blades and shorter dead tips (Figs. 1b \& 2a) form a more transparent light barrier. This may be due less to wave action (i.e. the mechanical thinning of the stand) than to (1) the lower shoot density as mentioned above and (2) the temperaturedependent growth delay resulting in shorter leaves Thus, despite a lower total light intensity at the deep site and the same per cent shading by the top layer, light conditions similar to those at the shallow site can be reached within the $P$. oceanica stand (Fig. 3c) due to structural compensation by the meadow. Naturally this is only true for blue and green spectra, since the red spectrum has almost disappeared at such depths (Fig. 3b).

\section{Light, leaf structure, and epiphytes}

The chloroplasts in Posidonia oceanica leaves are densely packed in the monolayered epidermis and are able to collect light immediately at the leaf surface. This represents the adaptation of $P$. oceanica to the aquatic environment and low light conditions (Mariani-Colombo et al. 1983), as opposed to terrestrial plants. The epidermis is composed of radially elongated cells with thickened outer walls and high contents of pectocellulose and acid polysaccharids (Mariani-Colombo et al. 1983). Differences in epidermal thickness were found between the convex outer surface and the concave inner surface of the leaf, with the former always being significantly thicker than the latter, which applies to both sites and to all leaf sections (Fig. 6a). This may increase the leaf's stability. On the other hand, larger cells may allow a more dense chloroplast and pigment packing in the epidermal cells of the light-exposed outer surface.
Leaf stability is also enhanced by small strands of thick-walled cellulosic fiber cells beneath the epidermal cells. There is no difference in the number of fiber cells between the inner and outer surfaces. However, the basal section (section $A$ ) is stiffer than section $B$ and $C$ of the same leaf, because it consists of up to $70 \%$ more cells (Fig. 6b). This is in agreement with the fact that epidermal thickness in the base section $\mathrm{A}$ is lowest as compared to the other sections (Fig. 6a). These factors may be responsible for the degree of bending of the leaf to form the typical shading layer between 30 and $50 \mathrm{~cm}$ above the bottom (see inserts in Figs. 3a, b $\& 6 b$ ). Moreover, it is remarkable that epidermal thickness and the number of fiber cells show a tendency towards lower values at the deep site, which may be due to a reduced mechanical strain exerted by wave action (Fig. 6a, b).

Epiphytes reduce the surface available for photosynthesis in Posidonia oceanica leaves and are thus responsible for direct shading. Species composition of epiphytes is influenced by the overall light gradient, which is composed by the light gradient in the water column and by selfshading of $P$. oceanica. In shading experiments in $P$. australis it was shown that after only 1 mo of reduced light conditions epiphyte biomass was significantly lower in shaded areas than in unshaded controls (Fitzpatrick \& Kirkman 1995). The composition of the epiphyte community also shifted and was dominated by invertebrates (bryozoans and tubebuilding worms) in shaded areas, whereas fleshy algae and coralline algae disappeared (Fitzpatrick \& Kirkman 1995). At our sampling sites the surfaces of short leaves $(<10 \mathrm{~cm}$ total length) and juvenile leaves $(<30 \mathrm{~cm})$ were hardly afflicted with epiphytes. Adult leaves (long leaves $>30 \mathrm{~cm}$ ) were colonized by epiphytes with the basal section (i.e. the youngest parts of the leaf, section A) showing the least epigrowth per surface area, epiphyte distribution increasing towards the tip. The highest loss of photosynthetic surface by epiphytism was in section $T$ (leaf tip) and to a lesser extent in section $\mathrm{B}$, which experienced some shading from epiphytes (Fig. 5). The distribution of the main epiphyte component, the red crustose coralline alga Fosliella farinosa, varied significantly between the 2 sites. At the deep site $F$. farinosa colonized particularly the outer surface of the leaves, whereas at the shallow site it preferred the inner surface (Fig. 5). This may be due to the strong curvature of the $P$. oceanica leaf along its length axis which leads to an additional shading of the concave inner surface, whereas the convex outer surface provides the epiphyte with enough light for its own photosynthesis. At the shallow site the red crustose coralline algae would, under the same conditions, be subjected to higher light intensity, which may cause pigment inactivation in this shade-preferring 
alga. Since $P$. oceanica leaf blades are longer at the shallow site, they easily bend and cover the stand horizontally so that the concave inner surface becomes the lower surface, and the convex outer side becomes the upper surface (see insert Fig. 6b). At the shallow sampling site $F$. farinosa grows at the inner surface (lower surface) and thus is shaded by the $P$. oceanica leaf itself. This observation may hint at a 'functional photoadaptation' in epiphytes within a $P$. oceanica meadow. What we cannot estimate in this discussion is to what extent UV radiation contributes to generating this pattern of epiphyte distribution-and this may be a topic for further investigation.

Acknowledgements. The investigations were carried out within a research project and field investigation of the Department of Zoology (University of Innsbruck) at the 'Station de Recherches Sous-Marines et Océanographiques' (STARESO) at Calví (Corse, France). The authors thank Drs D. Bay, P. Lejeune and M. Janssens for their kind hospitality and support during the investigations at the station. $\mathrm{M}$. Dorigatti and R. Hanel are gratefully acknowledged for their diving activities during the investigations, U. Hainz, S. Höfle S. Klammer, A. Sigg, and A. Trenkwalder for technical assistance, R. Schipflinger and J. Brenner for drawings of epiphytic areas and area determination, W. Salvenmoser and G. Sonntag for preparing light-microscopic sections and, Dr J. Wagner for important literature recommendations. Moreover, the authors thank Dr H. Forstner for lending his underwater light-intensity-meter, G. Buemberger for translating the manuscript and the 'Jörg-Klima-Fond' for financial support to J.D.V. Prof. W. Wieser is greatly acknowledged for critical reading of this manuscript.

\section{LITERATURE CITED}

Albergoni FG, Basso B, Tedesco G (1978) Considerations sur l'anatomie de Posidonia oceanica (Zosteraceae). Plant Syst Evol 130:191-201

Alcoverro T, Duarte CM, Romero J (1995) Annual growth dynamics of Posidonia oceanica: contribution of largescale versus local factors to seasonality. Mar Ecol Prog Ser 120:203-210

Augier H, Maudinas B (1977) Variations de la croissance et de la teneur en pigments de la phanerogame marine Posidonia oceanica dans le Parc National de Port-Cros en fonction de la profondeur et de la pollution. Etude préliminaire des paramètres physiologiques et biochimiques susceptibles de caractériser le degré d'impact de la pollution sur l'herbier de Posidonies. Trav Sci Parc Nat Port-Cros 3: $39-55$

Bay D (1984) A field study of the growth dynamics and productivity of Posidonia oceanica (L.) Delile in Calvi Bay, Corsica. Aquat Bot 20:43-64

Buia MC, Mazzella L (1991) Reproductive phenology of the Mediterranean seagrasses Posidonia oceanica (L.) Delile, Cymodocea nodosa (Ucria) Aschers., and Zostera noltil Hornem. Aquat Bot 40:343-362

Buia MC, Zupo V, Mazzella L (1992) Primary production and growth dynamics in Posidonia oceanica. PSZN I: Mar Ecol 13(1):2-16

Den Hartog C (1970) The sea-grasses of the world. North Holland Publ Co, Amsterdam.
Dennison WC, Alberte RS (1982) Photosynthetic responses of Zostera marina L. (eelgrass) to in situ manipulations of light intensity. Oecologia 55:137-144

Dennison WC. Alberte RS (1985) Role of daily light period in the depth distribution of Zostera marina L. (eelgrass). Mar Ecol Prog Ser 25:51-61

Dennison WC, Alberte RS (1986) Photoadaptation and growth of Zostera marina L. (eelgrass) transplants along a depth gradient. J Exp Mar Biol Ecol 98:265-282

Dirmhirn I (1964) Das Strahlungsfeld im Lebensraum. Akademische Verlagsgesellschaft, Frankfurt am Main

Drew EA (1978) Factors affecting photosynthesis and its seasonal variation in the seagrasses Cymodocea nodosa (Ucria) Aschers, and Posidonia oceanica (L.) Delile in the Mediterranean. J Exp Mar Biol Ecol 31:173-194

Duarte CM (1991) Seagrass depth limits. Aquat Bot 40: $363-377$

Enríquez S, Agustí S, Duarte CM (1992) Light absorption by seagrass Posidonia oceanica leaves. Mar Ecol Prog Ser 86: 201-204

Fitzpatrick J, Kirkman H (1995) Effects of prolonged shading stress on growth and survival of seagrass Posidonia australis in Jervis Bay, New South Wales, Australia. Mar Ecol Prog Ser 127:279-289

Kirk JTO (1994) Light and photosynthesis in aquatic ecosystems, 2nd edn. Cambridge University Press, Cambridge

Lorenzen CJ (1967) Determination of chlorophyll and phaeopigments: spectrophotometric equations. Limnol Oceanogr $12: 343-346$

Margalef R (1961) Variaciones intraspecificas de los pigmentos asimiladores en cloroficeas y fanerogamas acuaticas. Invest Pesq 9:111-118 (cited in Augier \& Maudinas 1977)

Mariani P, Rascio N, Cinelli F (1980) Osservazioni sulla struttura della foglia di Posidonia oceanica (L.) Delile dell'isola d'Ischia. G Bot Ital 114(3):115-135

Mariani-Colombo P, Rascio N, Cinelli F (1983) Posidonia oceanica (L.) Delile: a structural study of the photosynthetic apparatus. PSZN I: Mar Ecol 4(2):133-145

Ott JA (1979) Persistence of a seasonal growth rhythm in Posidonia oceanica (L.) Delile under constant conditions of temperature and illumination. Mar Biol Lett 1:99-104

Ott JA (1980) Growth and production in Posidonia oceanica (L.) Delile. PSZN I: Mar Ecol 1:47-64

Ott JA (1996) Meereskunde, 2nd edn. UTB Eugen Ulmer Verlag, Stuttgart

Pergent G, Pergent-Martini C (1991) Leaf renewal cycle and primary production of Posidonia oceanica in the bay of Lacco Ameno (Ischia, Italy) using lepidochronological analysis. Aquat Bot 42:49-66

Pergent G, Romero J, Pergent-Martini C, Mateo MA, Boudouresque CF (1994) Primary production, stocks and fluxes in the Mediterranean seagrass Posidonia oceanica. Mar Ecol Prog Ser 106:139-146

Pergent-Martini C, Rico-Raimondino V, Pergent G (1994) Primary production of Posidonia oceanica in the Mediterranean Basin. Mar Biol 120:9-15

Petit $C$ (1960) Contribution à l'étude des pigments photosynthétiques de deux phanérogames marines. DES Sci Nat, Fac Sc Marseille, 7 May 1960, p 1-49 (cited in Augier \& Maudinas 1977)

Pirc H (1986) Seasonal aspects of photosynthesis in Posidonia oceanica: influence of depth, temperature and light intensity. Aquat Bot 26:203-212

Richardson KC, Jarret L, Finke EH (1960) Embedding in epoxyresins for ultrathin sectioning in electron microscopy. Stain Technol 35:313-323

Riedl R (1966) Biologie der Meereshöhlen: Topographie, Fau- 
nistik und Ökologie eines unterseeischen Lebensraumes. Paul Parey, Hamburg

Semroud R, Verlaque R, Crouzet A, Boudouresque CF (1992)

On a broad-leaved form of the seagrass Posidonia oceanica (Posidoniacea) from Algiers (Algeria). Aquat Bot 43 $181-198$

Strickland JDH, Parsons TR (1968) A practical handbook of

Editorial responsibility: Otto Kinne (Editor),

Oldendorf/Luhe, Germany seawater analysis. Bull Fish Res Bd Can 167

Wittmann KJ (1984) Temporal and morphological variations on growth in a natural stand of Posidonia oceanica (L.) Delile. PSZN I: Mar Ecol 5:301-316

Wittmann KJ, Ott JA (1982) Effects of cropping on growth in the Mediterranean seagrass Posidonia oceanica (L.) Delile. PSZN I: Mar Ecol 3:151-159

Submitted: August 15, 1997; Accepted: December 3, 1997 Proofs received from author(s): February 16, 1998 